\title{
Cell organelles and fluorescence of parenchyma cells in Eucalyptus bosistoana sapwood and heartwood investigated by microscopy
}

\author{
Gayatri Mishra', David A. Collings ${ }^{2,3}$ and Clemens M. Altaner ${ }^{1 *}$
}

\begin{abstract}
Background: Eucalyptus bosistoana is currently investigated in New Zealand for its potential to produce naturally durable timber in short-rotation plantations. Little is known of heartwood formation in young trees. The objective of this study was to identify conventional and confocal microscopy methods which allow the observation of cell organelles and the chemical composition in the E. bosistoana parenchyma cells before and after heartwood formation.

Results: Nuclei, microtubules and peroxisomes in parenchyma cells of 2-year-old E. bosistoana stems were visualised by confocal microscopy combined with optimised immunolabelling protocols. Sequential staining of the tissue with toluidine blue and iodine/potassium iodide identified different cell organelles in parenchyma cells of sapwood. lodine/ potassium iodide stained starch (amyloplasts), while amido black stained proteins in sapwood. Fluorescence emission spectra confirmed the presence of chloroplasts in parenchyma of 2-year-old E. bosistoana. Fluorescence emission spectral (lambda) scans showed differences between parenchyma and fibre cells as well as sapwood and heartwood.

Conclusions: Physiological changes between sapwood and heartwood were visualised in parenchyma cells. Labelling of cell organelles was challenging due to unspecific binding and high background signals. Understanding heartwood formation is critical for the success of a plantation forest industry aiming to produce ground-durable timber, as heartwood formation is variable.
\end{abstract}

Keywords: Amyloplasts, Chloroplasts, Confocal microscopy, Extractives, Microtubules, Nuclei, Peroxisomes, Parenchyma cells, Wood (xylem)

\section{Background}

Wood formation (xylogenesis) in vascular plants is a complex biological process that includes cell division from secondary vascular cambium, cell elongation and differentiation, secondary cell wall deposition, programmed cell death and heartwood formation (Plomion et al., 2001). Wood consists of living and dead cells forming symplasmic and apoplasmic networks in trees. The apoplasmic system contains tracheids, vessels, and dead fibres. The symplasmic system integrates the living

\footnotetext{
* Correspondence: clemens.altaner@canterbury.ac.nz

${ }^{1}$ School of Forestry, The University of Canterbury, Christchurch 8140, New

Zealand

Full list of author information is available at the end of the article
}

parenchyma cells. These living parenchyma cells in the symplasmic system perform multiple roles in sugar transport and storage, embolism repair, defence against pathogens, and secondary modification of xylem cells (Nakaba et al., 2012).

Parenchyma refers to a tissue composed of living cells that varies widely by morphology and metabolism. Parenchyma cells are distributed throughout the plant body in different forms such as small clusters and strands or heterogeneously in tissues such as xylem and phloem (Pruyn \& Spicer, 2012). In secondary vascular tissue, parenchyma cells are typically oriented radially and axially forming a three-dimensional interconnected network of living cells (Spicer, 2005, 2014). 
Three distinct zones can be distinguished in the stems of older trees: sapwood, heartwood and a transition zone. Heartwood can be defined as an internal part of the stem, often darker in appearance than surrounding sapwood, devoid of living cells and water conduction, and in which the reserve materials (e.g. starch) have been removed. Some tree species additionally deposit heartwood substances imparting biotic resistance into this part of the stem (Bamber, 1964; Nakaba et al., 2012). Parenchyma cells remain alive for many years in the sapwood (Nakaba et al., 2011; Nakaba et al., 2008), retaining their intracellular organisation including organelles (nuclei, endomembranes, mitochondria, plastids, peroxisomes) and structural components such as the cytoskeleton (microtubules and actin microfilaments) (Fukuda, 2000; Funada, 2000; Spicer, 2005, 2014; Spicer \& Holbrook, 2007). The transition zone is the boundary between sapwood and heartwood. This is normally a narrow, often pale-coloured zone surrounding the heartwood that contains living cells that are usually devoid of starch, impermeable to liquids and with a moisture content lower than sapwood (Taylor et al., 2002). The extension and generation of heartwood takes place from the transition zone (Déjardin et al., 2010).

Heartwood formation is a genetically and metabolically controlled programmed cell death process, which leads to the formation of heartwood extractives (Magel et al., 2001). In the transition zone, an increase in metabolic activity of parenchyma cells occurs followed by a series of cumulative events (rapid synthesis of secondary metabolites called extractives, blockages of conducting elements by formation of tyloses and structural changes in pits) preceding the death of the parenchyma cells (Spicer, 2005). The extractives formed by the living parenchyma cells in the transition zone are released and deposited in the neighbouring cells, imparting durability and colour in some species. It is postulated that heartwood formation regulates the amount and function of sapwood, controlling water transport and storage of reserve materials (Spicer, 2005). Despite the physiological importance of heartwood, the biological aspects of its formation are still not well understood.

Heartwood is also of economic importance as only heartwood is coloured or naturally durable. Variations in colour and natural durability are caused by biologic differences in heartwood formation and directly impact on timber value. This is in particular true for a hardwood industry based on fast-growing, short-rotation plantations. Such sustainably managed plantations have the potential to satisfy the existing demand for coloured and naturally durable timbers, which are currently often unsustainably or illegally sourced from virgin tropical forests. The New Zealand Dryland Forests Initiative (NZDFI) has identified this opportunity for New Zealand (Millen et al., 2018) and has engaged in a research programme to support the establishment of Eucalyptus bosistoana F.Muell., a Class 1 durable timber (Australian Standard, AS5604-2005), in New Zealand.

The purpose of the study was to (a) identify microscopy techniques that are able to detect changes in chemical composition as well as cell organelles in E. bosistoana sapwood and heartwood and (b) get a better understanding of the changes occurring after heartwood formation.

\section{Materials and methods}

\section{Wood material and fixation}

Wood samples were collected in summer (December) 2014 from $E$. bosistoana trees grown at two different sites in the South Island of New Zealand. Stem sections of 2-year-old trees were collected from a research trial in Christchurch, Canterbury. Ten-centimetre-thick stem discs from 11-year-old trees were collected at breast height near Havelock, Marlborough. Heartwood and sapwood were visually distinguished in the fresh state on the samples and marked with a pencil. Radial strips $(\sim 4$ $\mathrm{cm}$ in tangential and $\sim 2 \mathrm{~cm}$ axial direction) were cut from the green samples and chiselled along the grain into smaller pieces. Approximately 30 wood pieces were fixed in $1 \mathrm{~L}$ of cytoskeleton stabilisation buffer as described in Mishra et al. (2018). Radial sections (10$20 \mu \mathrm{m}$ thick) were cut with a sledge microtome. Acetone treatment of tissue sections was performed at $-20^{\circ} \mathrm{C}$ for $20 \mathrm{~min}$ and subsequently washed with distilled water in a beaker under gentle stirring for $15 \mathrm{~min}$.

\section{Histochemistry}

A Nikon Eclipse 50i microscope with a Nikon digital sight DS-5 MC camera was used in transmitted light and fluorescence modes. Radial sections were stained with iodine/potassium iodide $(0.1 \%$ in water) to visualise starch grains, or amido black $(0.2 \%$ in $7 \%$ acetic acid) to label proteins (Islam \& Begum, 2012; Nakaba et al., $2012)$, or toluidine blue ( $0.1 \%$ in water). Sequential labelling with toluidine blue staining followed by potassium iodide was also used. Sections were mounted in glycerol.

Sections were stained with either Sudan IV (1\% in 70\% ethanol) (Begum et al., 2010) or Nile red (dissolved in 0.5\% $\mathrm{H}_{2} \mathrm{SO}_{4}$ ) (Greenspan et al., 1985) to highlight lipid droplets. Protein stains such as Coomassie brilliant blue R-250 (0.25 $\mathrm{g}$ in $90 \mathrm{~mL}$ of methanol: distilled water $(1: 1, v / v)$ and $10 \mathrm{~mL}$ of glacial acetic acid) and Ponceau S $(0.1 \%(w / v)$ in $5 \%$ acetic acid) as well as colour-based DNA stains such as acetocarmine (1\% in acetic acid) (Islam \& Begum, 2011; Nakaba et al., 2006) and methyl green pyronin (1\% in acetate buffer solution comprised of glacial acetic acid and sodium acetate) (Potvin, 1979) were unsuccessfully used on sapwood and heartwood sections. Similarly, fluorescent DNA stains such as DAPI (4', 6-diamidino-2-phenylindole) $(1 \mu \mathrm{L}$ in $999 \mu \mathrm{L}$ distilled water) and propidium iodide $(1 \mu \mathrm{L}$ 


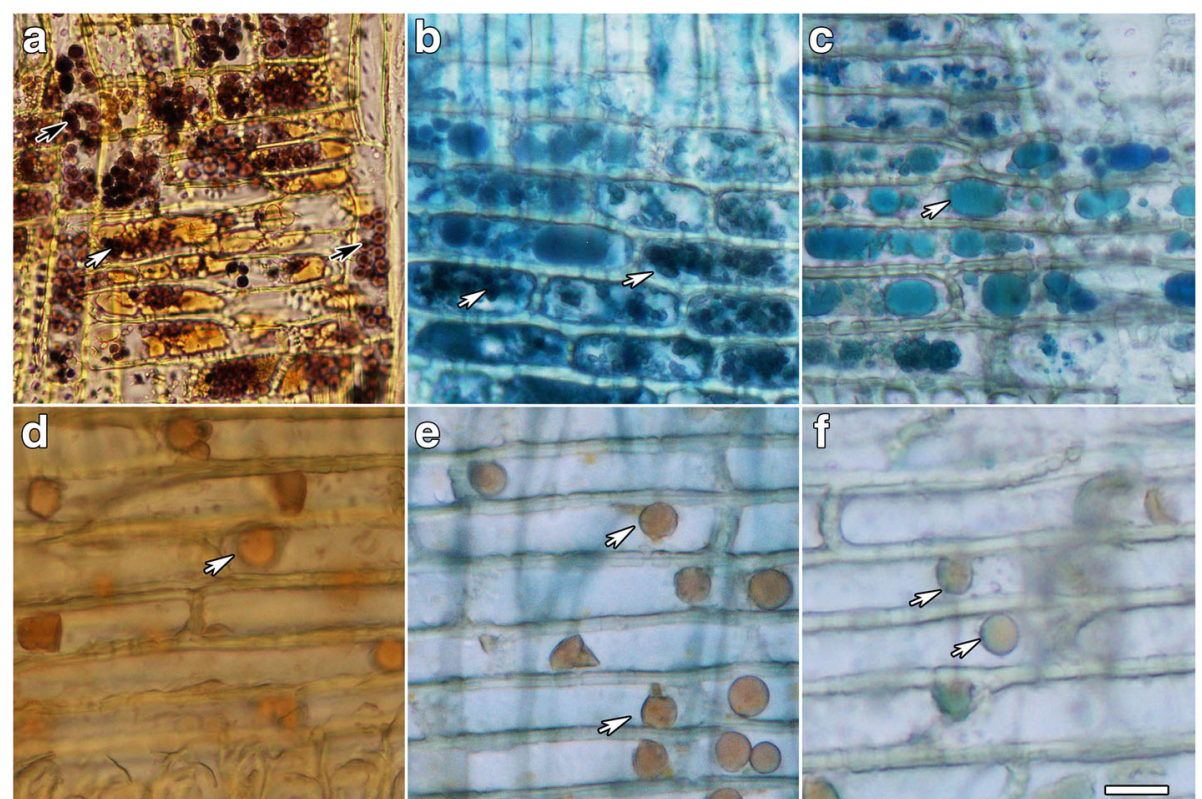

Fig. 1 Histochemical staining of ray parenchyma in sapwood (top row) and heartwood (bottom row) from an 11-year-old E. bosistoana tree. Starch granules were stained black with iodine/potassium iodide in radial (white arrows) and axial (black arrows) parenchyma of sapwood but were absent in heartwood (a, d). Proteins and vacuoles (arrows) were labelled bluish-black with amido black in sapwood but were absent from heartwood (b, e). Vacuoles (arrows) labelled bluish with toluidine blue in parenchyma of sapwood but were absent or breaking down in heartwood (c, f). Round structures (arrows) in heartwood (d, e, f) were likely heartwood extracts synthesised in ray parenchyma cells. These round structures were not evident in sapwood. Scale bar $20 \mu \mathrm{m}$

in $999 \mu \mathrm{L}$ distilled water) and Syto- $13(1 \mu \mathrm{L}$ in $999 \mu \mathrm{L}$ distilled water) were found to be unreliable markers for living nuclei as these dyes bound to the cell walls and did not clearly resolve nuclei.

\section{Immunofluorescence microscopy}

Sections were labelled against monoclonal antibodies to visualise microtubules (mouse anti- $\alpha$-tubulin, clone B512, Sigma-Aldrich, St Louis, MO, USA), nuclei (histone proteins or anti-histone H3, catalogue number 07-690, Merck Millipore, Billerica, MA, USA) and peroxisomes (rabbit polyclonal anti-cottonseed catalase, courtesy of Dr. Richard Trelease, University of Arizona) (Kunce et al. 1988). The sections were observed with a Leica SP5 confocal microscope system operating on a DMI6000 inverted microscope with $\times 20$ NA 0.7 and $\times 63$ NA 1.3 glycerol immersion lenses (Leica, Wetzlar, Germany) after applying fluorescein and Cy5 labelled secondary antibodies. The secondary antibodies used were mixtures of either goat anti-rabbit-Cy 5 (Jackson Immunoresearch, West Grove PA, USA) and sheep anti-rabbit-fluorescein (Silenus, Boronia, Vic, Australia) or goat anti-mouse-Cy5 (Jackson Immunoresearch) and sheep anti-mouse-fluorescein (Silenus). The detailed procedure was described by Mishra et al. (2018).

For immunolocalisation of nuclei, sections were post -fixed with FAA solution (10\% $(v / v)$ formaldehyde, 5\% $(v / v)$ acetic acid and 50\% $(v / v)$ ethanol) overnight. This step, based on Nic-Can et al. (2013), reduced the background fluorescence and promoted antibody binding. Samples not post-fixed with FAA showed minimal labelling with the antibody. Primary antibody controls were also negative.

\section{Confocal microscopy}

Variations in the colour of autofluorescence from wood samples, different cells and organelles were detected by recording fluorescence emission spectra using excitation wavelengths of 405 and $488 \mathrm{~nm}$. Emissions were collected from 420 to 700 and 500 to $700 \mathrm{~nm}$, respectively. Image intensities from organelles, parenchyma or from selected fibre cells were quantified using the Image software (FIJI version $1.47 \mathrm{v}$, National Institute of Health, Bethesda, MD, USA) using the 'Plot $\mathrm{Z}$ axis profile' function.

\section{Results and discussion}

A range of cytological features associated with the transition of living parenchyma cells in sapwood to dead cells in heartwood were investigated by microscopy in radial wood sections collected from 2-year-old and 11-year-old E. bosistoana trees. 


\section{Histochemical observations}

Three different histochemical stains labelled living parenchyma. Starch, which is localised in amyloplasts, was detected as black granules with iodine/potassium iodide stain. Starch labelling was present in the radial (white arrows, Fig. 1a) and axial (black arrows, Fig. 1a) parenchyma cells of sapwood but was absent from heartwood (Fig. 1d). This was consistent with previously described transitions of parenchyma cells in a variety of different angiosperm and gymnosperm species. The presence of starch was reported in sapwood and its absence from heartwood in Larix kaempferi (Lamb.) Carr. (Japanese larch) (Islam et al., 2012) as well as in Tectona grandis (L.f.) Lam. (teak) (Islam \& Begum, 2011). Consistent with their observations, our results suggested that starch depletion in ray cells was associated with cell death.

The second histochemical stain used was amido black, which stained proteins a bluish-black colour. This showed that parenchyma cells in sapwood retained proteins indicating that they remained alive (arrows, Fig. 1b). The parenchyma in heartwood lacked proteins, which indicated that it had undergone cell death (Fig. 1e). Again, these observations matched literature reports. Islam and Begum (2012) investigated Artocarpus heterophyllus Lam. (jackfruit) and reported the presence of more protein in younger ray parenchyma cells than in ray parenchyma of older wood. Their results suggested that disappearance of proteins in ray cells was associated with cell death, which coincided with our observations. Similar observations were also reported by Datta and Kumar (1987) concerning the presence of starch and proteins in parenchyma cells of inner and outer sapwood of $T$. grandis and their absence in heartwood. However, it needs to be taken into account that the starch and protein content in xylem was reported to vary among seasons and species (Begum et al., 2013; Nakaba et al., 2012). The lowest reserves are typically present in spring after bud flush and the highest during winter dormancy (Rossi et al., 2007; Rossi et al., 2008). Round structures in heartwood (arrows, Fig. 1d-f) sections were likely heartwood extractives synthesised in ray parenchyma cells that were not evident in sapwood (Fig. 1a-c). This was consistent with previously reported observations of polyphenols in ray parenchyma cells of Pinus densiflora Siebold \& Zucc. and P. rigida Mill. (Nakaba et al., 2008).

The third histochemical stain was toluidine blue. This stained the vacuoles and other organelles of sapwood a bluish colour indicating that they were alive (arrows, Fig. 1c). No indications of vacuoles were observed in heartwood (Fig. 1f). Fukuda (2000) suggested that the collapse of the vacuoles could result in the release of hydrolytic enzymes that degrade cell organelles such as nuclei (Kuriyama \& Fukuda, 2002). Disruption of vacuoles followed by disappearance of nuclei was observed in ray tracheids located further inside the stem of $P$. densiflora (Nakaba et al., 2011). The identification of the small organelles labelled by toluidine blue remains unclear. However, sequential staining of the same section with toluidine blue (arrows, Fig. 2a) followed by iodine/potassium iodide (arrows, Fig. 2b) confirmed that the toluidine blue-labelled organelles were distinct from the amyloplasts.

Several other stains were also investigated but these did not provide good labelling in E. bosistoana. Stains for lipid droplets including Sudan IV, previously used in wood samples (Begum et al., 2010; Begum et al., 2013; Islam et al., 2012), and Nile red (Greenspan et al., 1985) failed to give good labelling. These observations suggest that unlike T. grandis (Islam \& Begum, 2011) and Cryptomeria japonica (L. f.) D.Don. (Begum et al., 2010), lipid droplets were mostly absent from the parenchyma of $E$. bosistoana samples in summer. However, it needs to be taken into account that, similar to the starch and protein content, the lipid content in xylem has been reported to vary among seasons and species (Begum et al., 2013). Similarly, two protein stains that are more commonly associated with biochemistry than histochemistry,

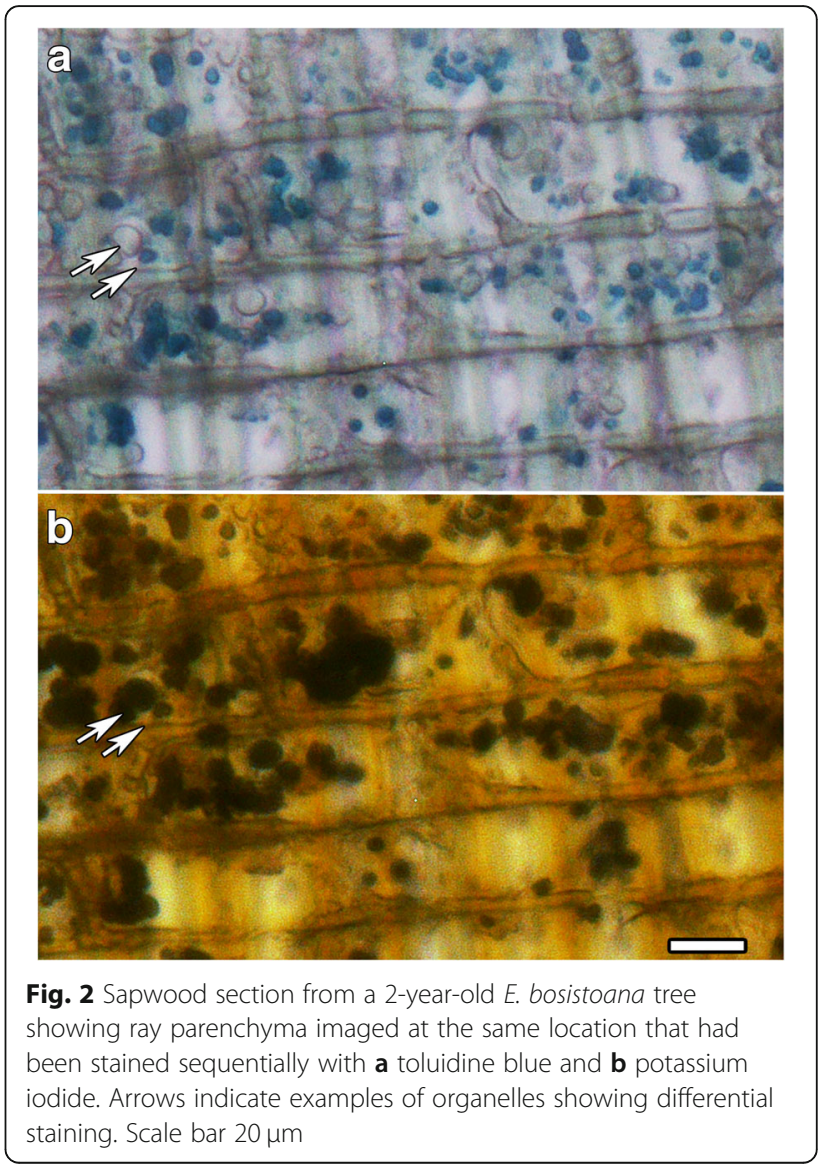


Coomassie brilliant blue R-250 and Ponceau S, failed to provide clear staining of ray parenchyma.

\section{Autofluorescence}

A significant problem for the analysis of E. bosistoana wood was the fact that the samples were autofluorescent at most wavelengths. This autofluorescence derived from at least three different sources.

The main source of autofluorescence was from the vacuoles in parenchyma cells which, in sapwood, were fluorescent at all wavelengths (arrows, Fig. 3b-d), but degraded in heartwood (Fig. 3f-h). The observations led us to use spectral imaging (lambda scanning) with excitation at 405 nm (Fig. 3i), $488 \mathrm{~nm}$ (Fig. 3j) and $561 \mathrm{~nm}$ (Fig. 3k), and with the emission spectra from the sapwood vacuoles quantified from 420 to $700 \mathrm{~nm}, 500$ to $700 \mathrm{~nm}$ and 560 to
$700 \mathrm{~nm}$ respectively. The observations showed that emission spectra were shifted to longer wavelengths as excitation wavelength increased. Fluorescence peaked at $508 \mathrm{~nm}$ using $405 \mathrm{~nm}$ excitation, at $575 \mathrm{~nm}$ for 488 $\mathrm{nm}$ excitation and at about $640 \mathrm{~nm}$ for $561 \mathrm{~nm}$ excitation.

The second source of autofluorescence was from the cell walls of both the parenchyma and fibre cells. Fluorescence emission spectra of parenchyma and fibre cells of sapwood and heartwood indicated differences in chemical composition. Using $405 \mathrm{~nm}$ excitation, the emission spectra for fibre cells showed a peak in fluorescence at $480 \mathrm{~nm}$ in both sapwood and heartwood (Fig. 4a) whereas the emission peak for the parenchyma cell walls was at a longer wavelength of almost $488 \mathrm{~nm}$ in sapwood and at an even longer wavelength of $500 \mathrm{~nm}$

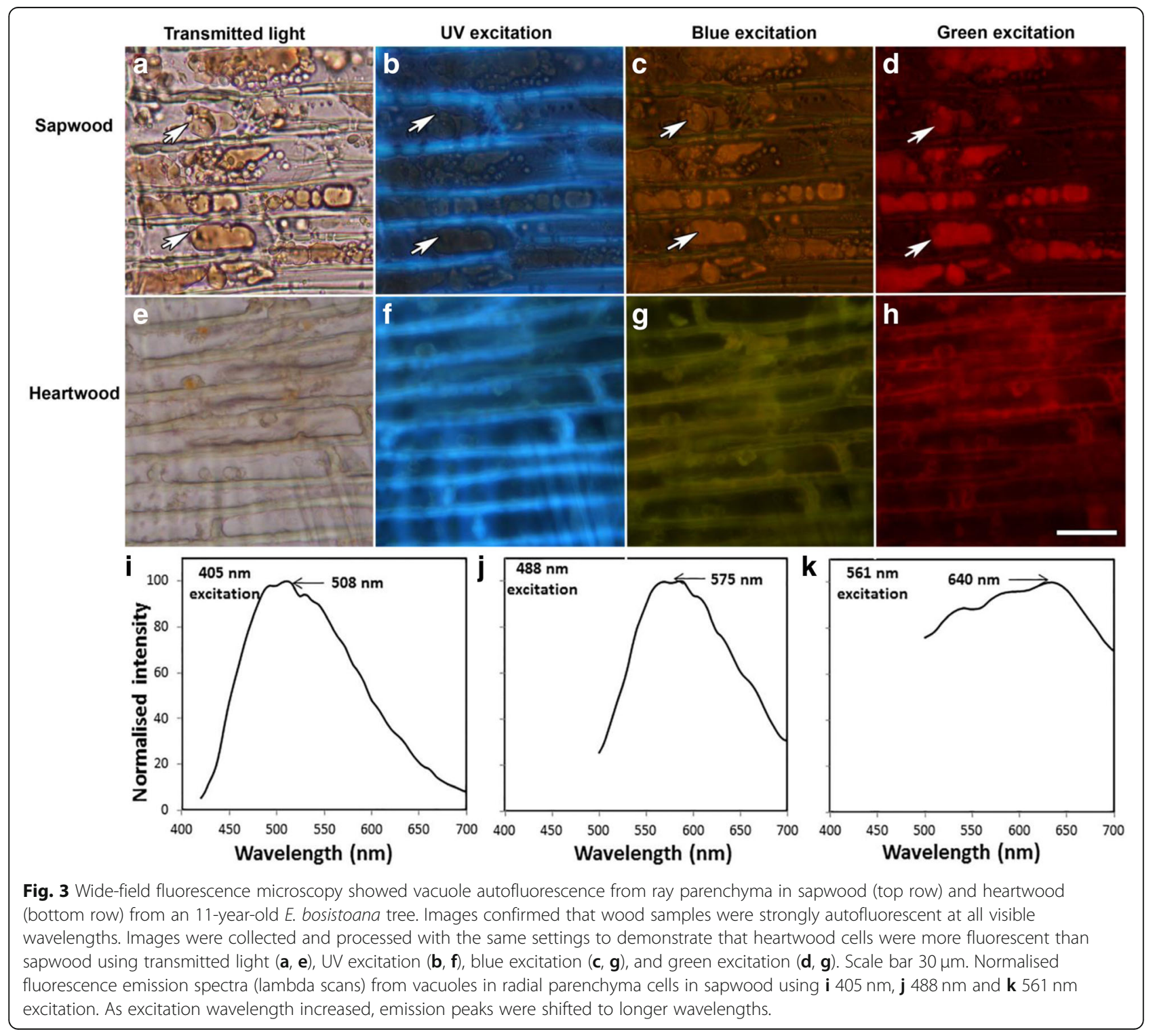




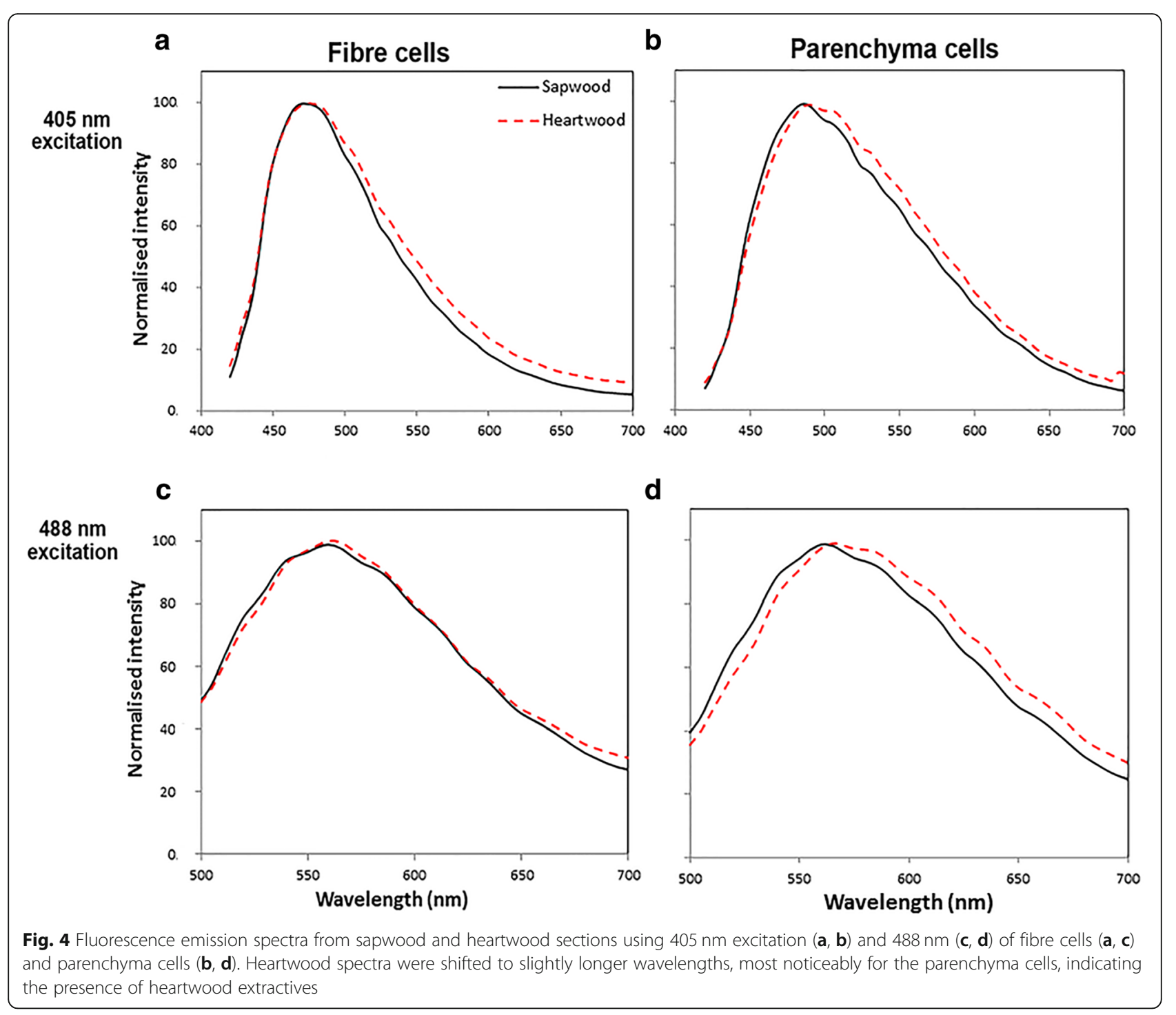

in heartwood (Fig. 4b). Using $488 \mathrm{~nm}$ excitation, the emission spectra for fibre cells showed a peak in fluorescence at $560 \mathrm{~nm}$ in both sapwood and heartwood (Fig. 4c) whereas the emission peaks for the parenchyma cell walls were at a longer wavelength in sapwood (565 $\mathrm{nm})$ and heartwood $(570 \mathrm{~nm})$ (Fig. 4d). These observations showed that for 11-year-old E. bosistoana, the transition from sapwood to heartwood did not markedly change the fluorescence emission spectra of fibre cells, whereas the emission spectra for parenchyma cell walls showed consistent shift in the emission peak associated with changes in the cell wall after cell death.

Variations in the location and intensity of the peaks were likely caused by the presence of extractives (Koch \& Kleist, 2001; Nakaba et al., 2012). A solvent such as acetone has been shown to remove large parts of the extractives from E. bosistoana heartwood (Van Lierde, 2013). Spectral imaging was conducted to determine whether or not the compounds present within the cell wall might be extracted by solvents. Acetone treatments resulted in few differences between the fluorescence patterns of fibre cells (Fig. 5a) and ray parenchyma (Fig. 5b) in heartwood sections suggesting that the extractives dominating fluorescence of $E$. bosistoana heartwood were not significantly removed by the acetone treatment. While dried acetone extracted heartwood powder maintained a darker colour than extracted sapwood powder (data not shown), a contributing factor to the small differences in fluorescence observed here could have been that the fixation treatment of the wood during sample preparation also bound the extractive compounds to the cell walls.

Heartwood of 6-year-old E. bosistoana was reported to contain between 1 and $15 \%$ of ethanol-soluble material ( $\mathrm{Li}$ \& Altaner, 2018). No detailed description of the chemical composition of these extracts has been published. Catechin was observed to be a major compound in the heartwood of 

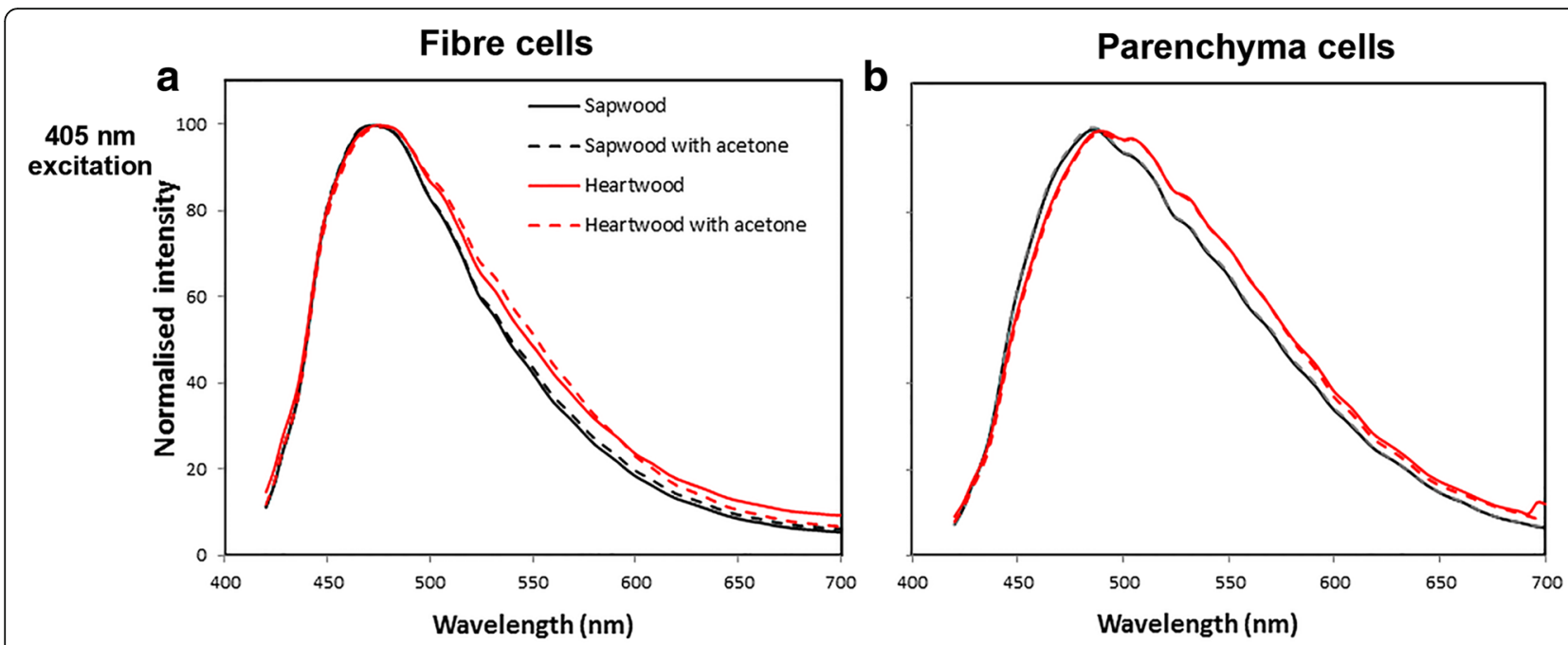

Fig. 5 Fluorescence emission spectra from sapwood and heartwood sections with and without acetone wash using $405 \mathrm{~nm}$ excitation of fibre cells (a) and parenchyma cells (b). Heartwood spectra were shifted to slightly longer wavelengths. No difference between the fluorescence patterns of $\mathbf{a}$ fibre cells and $\mathbf{b}$ ray parenchyma in heartwood sections without and with acetone treatment were observed

E. camaldulensis F. Muell (Benouadah et al., 2018), and more generally, heartwood extractives were reported to predominately be comprised of phenolic compounds, e.g. tannins (Hillis, 1972, 1991). Various tannins, e.g. ellagitannins and condensed tannins, have been described in the heartwood extracts of other Eucalyptus species (Hillis \& Carle, 1960, 1962; Stewart et al., 1953; Taylor et al., 2002).

The third source of autofluorescence was present only in the sapwood of the 2-year-old trees. Sections showed a scattering of small organelles with red autofluorescence (arrows, Fig. 6a). The pigment was identified as chlorophyll and the organelles as chloroplasts because the pigment was extracted by methanol (Fig. 6b) and acetone washes, and as spectral analysis showed an emission peak at $680 \mathrm{~nm}$ (Fig. 6c). In contrast, no indications of chlorophyll were observed in heartwood of $E$. bosistoana trees close to the pith where the cells had undergone cell death (data not shown). This was consistent with other reports showing that chloroplasts can exist within sapwood, for example, similar observations of red, chlorophyll autofluorescence from xylem ray cells and pith of E. angustifolia and E. globulus (Dima et al. 2006). Also, similar observations of chloroplasts present in sapwood were reported by van Cleve and co-workers based on absorption spectra maxima at 432 $\mathrm{nm}$ and $664 \mathrm{~nm}$ in methanol extracts from leaves, bark and pith of poplar (Populus $\times$ canadensis) (van Cleve et al., 1993). Furthermore, chlorophyll content were shown to depend on the age of the stem and its exposure to light (van Cleve et al., 1993; Dima et al., 2006; Larcher et al., 1988; Maxwell \& Johnson, 2000; Saranpää, 1988). Published reports also provide evidence for an age-dependant decrease in stem chlorophyll content in a wide range of tree species (Pfanz et al., 2002).

\section{Immunolocalisation of organelles and structures}

Organelles and cytoplasmic structures of living parenchyma cells in sapwood of 2-year-old E. bosistoana trees were visualised by immunolabelling. Fixation, extraction and labelling procedures were based on conventional immunofluorescence imaging methods (Collings and Wasteneys, 2005) that were modified to work with radial wood sections. Immunolabelling was screened visually using fluorescence from fluorescein-tagged secondary antibodies, but the high autofluorescence at these wavelengths (Fig. 3) prompted the simultaneous use of two secondary antibodies, with confocal imaging conducted in the far-red with Cy5-tagged secondary antibodies.

Microtubules were visible as lines in and around the edges of both ray (white arrows, Fig. 7a) and axial (black arrows, Fig. 7a) parenchyma cells in sapwood and were absent from heartwood. These observations matched those of Nakaba and co-workers who reported microtubules in the outer xylem parenchyma cells of $P$. densiflora Siebold \& Zucc. and Abies sachalinensis F.Schmidt. (Nakaba et al., 2006, Nakaba et al., 2008, Nakaba et al., 2013). Similarly, peroxisomes were immunolabelled in both the radial (white arrows, Fig. 7b) and axial (black arrows, Fig. 7b) parenchyma of sapwood. These peroxisomes were small, round organelles that were less than $2 \mu \mathrm{m}$ in diameter and were abundant in the parenchyma. They too were absent from heartwood. Peroxisomes act as a source of enzymes such as polyphenol oxidases or peroxidases that contribute to the oxidation of phenolic 

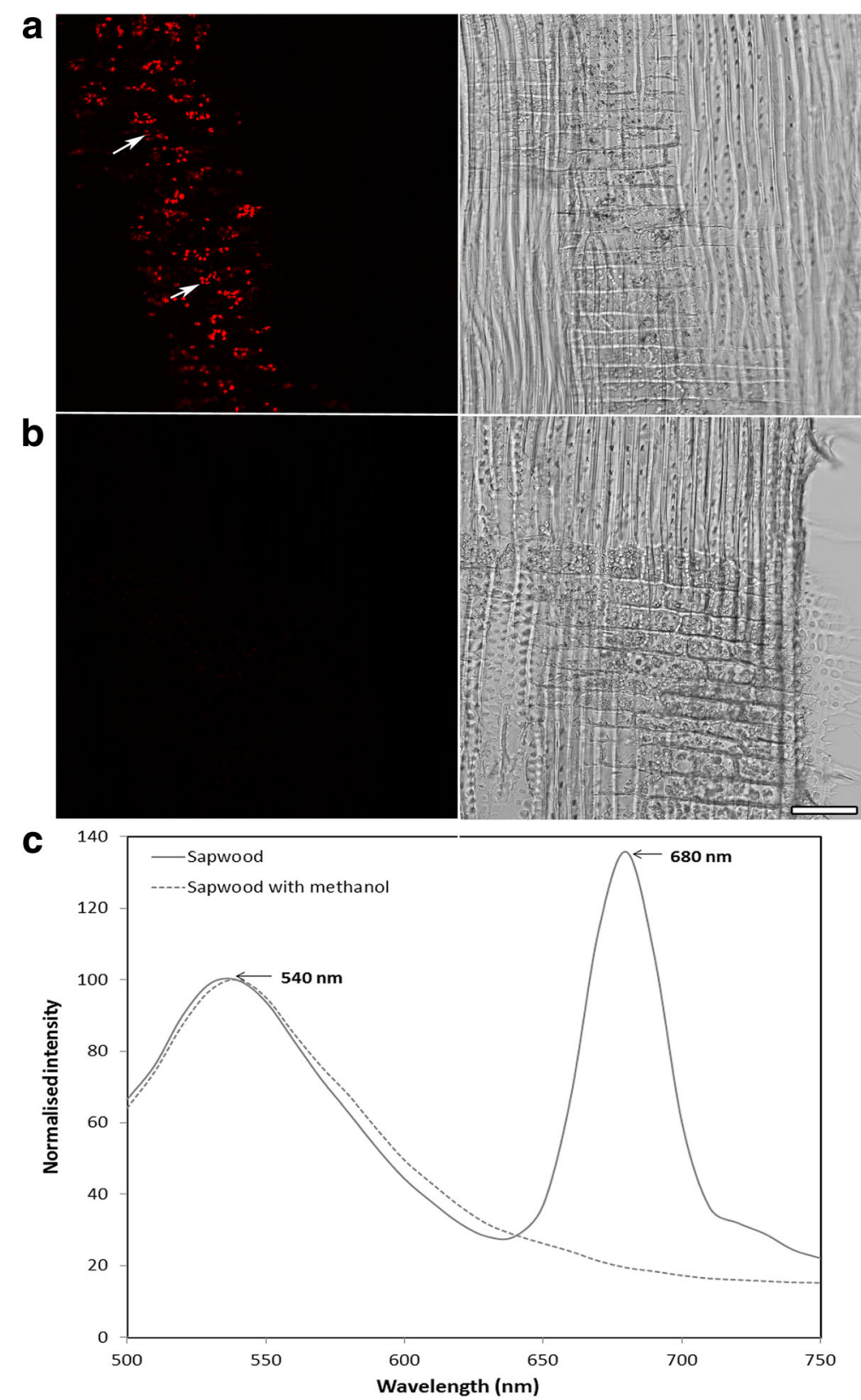

Fig. 6 Sapwood contained chloroplasts. Concurrent confocal fluorescence (left) and transmitted light (right) images of sapwood sections treated without (a) and with methanol and $\mathbf{b}$ from a 2-year-old E. bosistoana tree. Ray parenchyma cells in sections that lacked the methanol treatment contained chloroplasts that fluoresced red using $488 \mathrm{~nm}$ excitation (arrows in a) but these organelles were not visible following methanol washes which indicated that the chlorophyll had been washed out (b). Scale bar $50 \mu \mathrm{m}$. Fluorescence emission spectra using $488 \mathrm{~nm}$ excitation from sapwood ray parenchyma treated without and with methanol (c)

heartwood compounds in Juglans nigra L. resulting in the brown colour of its heartwood (Dehon et al., 2002). Phenolic compounds are also common in heartwood extracts of Eucalyptus species (Da Costa \& Rudman, 1958; Hart \& Hillis, 1974; Hathway \& Seakins, 1959; Hillis, 1956, 1991; Taylor et al., 2002).

Conventional nuclear stains failed in these E. bosistoana sections. Colour-based DNA stains such as acetocarmine and methyl green pyronine did not work well because they caused too much background signal. Similarly, fluorescent DNA stains such as DAPI (4', 6 -diamidino-2-phenylindole), propidium iodide and Syto-13 were unreliable markers for living nuclei as these dyes bound to the cell walls and did not clearly resolve nuclei. Instead, nuclei were labelled with antibodies against the $\mathrm{H} 3$ histone protein (Nic-Can et al., 


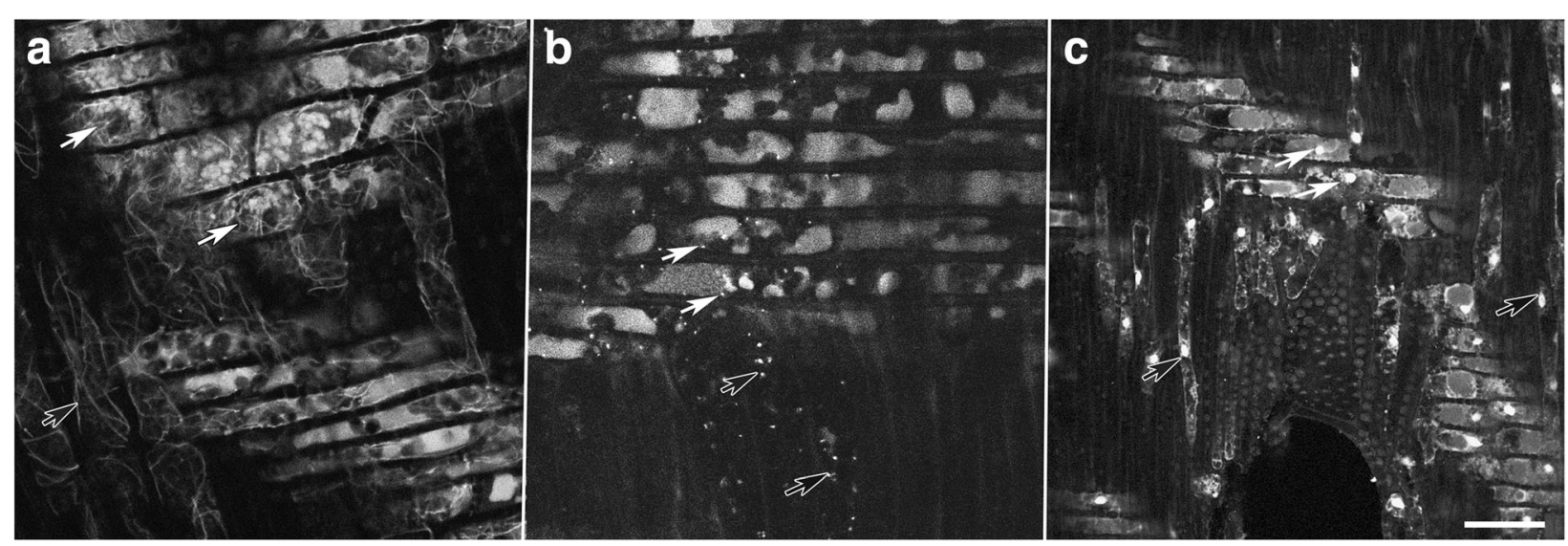

Fig. 7 Immunolabelling allowed visualisation of organelles in living ray (white arrows) and axial (black arrows) parenchyma cells of sapwood from a 2-year-old E. bosistoana tree. Images are maximum projections of confocal optical sections using $633 \mathrm{~nm}$ excitation of Cy5 and collected between 650 and $700 \mathrm{~nm}$ where background autofluorescence was less severe. No labelling was seen in heartwood sections nor in primary antibody controls. Microtubules (arrows) labelled with mouse monoclonal anti-a-tubulin antibodies (a). Peroxisomes (arrows) labelled with rabbit polyclonal anti-catalase antibodies (b). Nuclei (arrows) labelled with rabbit polyclonal anti-histone antibodies (c). Scale bar $50 \mu \mathrm{m}$

2013). The use of this antibody was complex, with samples requiring post-fixation in FAA for the histone antigen to become immunoreactive. Nuclei were observed in both ray (white arrows, Fig. 7c) and axial (black arrows, Fig. 7c) parenchyma cells of sapwood. The presence of nuclei indicated that parenchyma cells remained alive in the sapwood. Similar observations were reported for Populus sieboldii L. $\times$ P. grandidentata L. and Abies sachalinensis F. Schmidt. (Nakaba et al., 2012, Nakaba et al., 2013).

\section{Conclusion}

Cell organelles and storage materials could be visualised in the living parenchyma cells in sapwood of 2-year-old $E$. bosistoana trees by immunolabelling and conventional histochemical staining. Extractives were localised in heartwood of 11-year-old E. bosistoana trees. It has been shown in this study that it is possible to use microscopy with appropriate staining to study physiological processes during heartwood formation. However, autofluorescence and unspecific staining made the use of several common staining techniques impractical. Investigating heartwood formation will aid the development of a hardwood industry based on E. bosistoana, which needs to ensure consistent wood properties. Early selections for heartwood in breeding programmes (Li et al., 2018) rely on the correct identification of fully developed heartwood (Mishra et al., 2018). Silvicultural practices and site influences on heartwood formation have been reported and need to be understood.

\section{Abbreviations}

DAPI: 4', 6-Diamidino-2-phenylindole; DNA: Deoxyribonucleic acid; FAA: Formaldehyde-acetic acid-ethanol; NZDFI: New Zealand Dryland Forests Initiative

\section{Acknowledgements}

The authors thank the New Zealand Dryland Forests Initiative (NZDFI) for supplying the samples and Manfred Ingerfeld (School of Biological Sciences) for assistance with confocal microscopy.

\section{Funding}

The research was funded by the 'Speciality Wood Products Partnership' (MBIE-FFRX1501).

Availability of data and materials

Please contact author for data requests.

\section{Authors' contributions}

GM, DC and CA conceived and designed the research. GM conducted experiments. GM and DC analysed the images and spectral data. GM, DC and CA wrote and edited the manuscript. All authors read and approved the final manuscript.

Ethics approval and consent to participate Not applicable.

\section{Consent for publication \\ Not applicable.}

\section{Competing interests}

The authors declare that they have no competing interests.

\section{Publisher's Note}

Springer Nature remains neutral with regard to jurisdictional claims in published maps and institutional affiliations.

\section{Author details}

${ }^{1}$ School of Forestry, The University of Canterbury, Christchurch 8140, New Zealand. ${ }^{2}$ School of Biological Sciences, The University of Canterbury, Christchurch 8140, New Zealand. '3 School of Environmental \& Life Sciences, The University of Newcastle, Callaghan, NSW 2308, Australia.

Received: 6 March 2018 Accepted: 6 November 2018 Published online: 07 December 2018

References

AS5604. (2005). Timber-Natural durability ratings: Standards Australia Sydney. Bamber, R. (1964). Sapwood and heartwood: A review. Forestry Abstracts, 46, 567-580. 
Begum, S., Nakaba, S., Oribe, Y., Kubo, T., \& Funada, R. (2010). Changes in the localization and levels of starch and lipids in cambium and phloem during cambial reactivation by artificial heating of main stems of Cryptomeria japonica trees. Annals of Botany, 106, 885-895.

Begum, S., Nakaba, S., Yamagishi, Y., Oribe, Y., \& Funada, R. (2013). Regulation of cambial activity in relation to environmental conditions: Understanding the role of temperature in wood formation of trees. Physiologia Plantarum, 147, 46-54.

Benouadah, N., Pranovich, A., Aliouche, D., Hemming, J., Smeds, A., \& Willför, S. (2018). Analysis of extractives from Pinus halepensis and Eucalyptus camaldulensis as predominant trees in Algeria. Holzforschung, 72, 97-104.

Collings, D. A., \& Wasteneys, G. O. (2005). Actin microfilament and microtubule distribution patterns in the expanding root of Arabidopsis thaliana. Canadian Journal of Botany, 83, 579-590.

Da Costa, E., \& Rudman, P. (1958). The causes of natural durability in timber I. The role of toxic extractives in the resistance of tallowwood (Eucalyptus microcorys) to decay. Australian Journal of Biological Sciences, 11, 45-57.

Datta, S., \& Kumar, A. (1987). Histochemical studies of the transition from sapwood to heartwood in Tectona grandis. IAWA Journal, 8, 363-368.

Dehon, L., Macheix, J., \& Durand, M. (2002). Involvement of peroxidases in the formation of the brown coloration of heartwood in Juglans nigra. Journal of Experimental Botany, 53, 303-311.

Déjardin, A., Laurans, F., Arnaud, D., Breton, C., Pilate, G., \& Leplé, J.-C. (2010). Wood formation in angiosperms. Comptes Rendus Biologies, 333, 325-334.

Dima, E., Manetas, Y., \& Psaras, G. (2006). Chlorophyll distribution pattern in inner stem tissues: Evidence from epifluorescence microscopy and reflectance measurements in 20 woody species. Trees, 20, 515-521.

Fukuda, H. (2000). Programmed cell death of tracheary elements as a paradigm in plants. Plant Molecular Biology, 44, 245-253.

Funada, R. (2000). Control of wood structure. In P. Nick (Ed.), Plant Microtubules (Vol. 11, pp. 51-81). Berlin, Heidelberg: Springer.

Greenspan, P., Mayer, E. P., \& Fowler, S. D. (1985). Nile red: A selective fluorescent stain for intracellular lipid droplets. The Journal of Cell Biology, 100, 965-973.

Hart, J. H., \& Hillis, W. (1974). Inhibition of wood-rotting fungi by stilbenes and other polyphenols in Eucalyptus sideroxylon. Phytopathology, 64, 939-948.

Hathway, D., \& Seakins, J. (1959). Hydroxystilbenes of Eucalyptus wandoo. Biochemical Journal, 72, 369.

Hillis, W. (1956). Leucoanthocyanins as the possiblig precursors of extractives in woody tissues. Australian Journal of Biological Sciences, 9, 263-280.

Hillis, W. (1972). Formation and properties of some wood extractives. Phytochemistry, 11(4), 1207-1218

Hillis, W. (1991). Eucalypts: Chemistry, uses. Appita Journal, 44, 239-244.

Hillis, W., \& Carle, A. (1960). The formation of phenolic substances in Eucalyptus gigantea and Eucalyptus sieberiana. Biochemical Journal, 74, 607.

Hillis, W., \& Carle, A. (1962). The origin of the wood and bark polyphenols of eucalyptus species. Biochemical Journal, 82, 435.

Islam, M., \& Begum, S. (2012). Histochemical and anatomical studies of phloem and xylem cells of jackfruit (Artocarpus heterophyllus) tree. International Journal of Natural Sciences, 2, 01-07.

Islam, M., Begum, S., Nakaba, S., \& Funada, R. (2012). Distribution and pattern of availability of storage starch and cell death of ray parenchyma cells of a conifer tree (Larix kaempferi). Research Journal of Recent Sciences, 1, 28-37.

Islam, M. A., \& Begum, S. (2011). Distribution of starch, lipid and nuclei in xylem and phloem of Tectona grandis Linn. Journal of Bio-Science, 19, 29-35.

Koch, G., \& Kleist, G. (2001). Application of scanning UV microspectrophotometry to localise lignins and phenolic extractives in plant cell walls. Holzforschung, 55, 563-567.

Kunce, C. M., Trelease, R. N., \& Turley, R. B. (1988). Purification and biosynthesis of cottonseed (Gossypium hirsutum L.) catalase. Biochemical Journal, 251, 147-155.

Kuriyama, H., \& Fukuda, H. (2002). Developmental programmed cell death in plants. Current Opinion in Plant Biology, 5, 568-573.

Larcher, W., Lütz, C., Nagele, M., \& Bodner, M. (1988). Photosynthetic functioning and ultrastructure of chloroplasts in stem tissues of Fagus sylvatica. Journal of Plant Physiology, 132, 731-737.

Li, Y., \& Altaner, C. (2018). Predicting extractives content of Eucalyptus bosistoana F. Muell. Heartwood from stem cores by near infrared spectroscopy. Spectrochimica Acta Part A: Molecular and Biomolecular Spectroscopy, 198, 78-87.

Li, Y., Apiolaza, L. A., \& Altaner, C. (2018). Genetic variation in heartwood properties and growth traits of Eucalyptus bosistoana. European Journal of Forest Research, 137, 1-8.

Magel, E. A., Hillinger, C., Wagner, T., \& Höll, W. (2001). Oxidative pentose phosphate pathway and pyridine nucleotides in relation to heartwood formation in Robinia pseudoacacia L. Phytochemistry, 57, 1061-1068.
Maxwell, K., \& Johnson, G. N. (2000). Chlorophyll fluorescence-a practical guide. Journal of Experimental Botany, 51, 659-668.

Millen, P., Ballekom, S. v., Altaner, C., Apiolaza, L., Mason, E., McConnochie, R., Morgenroth, J., \& Murray, T. (2018). Durable eucalypt forests - a multi-regional opportunity for investment in New Zealand drylands. New Zealand Journal of Forest Science, 63, 11-23.

Mishra, G., Collings, D. A., \& Altaner, C. M. (2018). Physiological changes during heartwood formation in young ( 6 year-old) Eucalyptus bosistoana. International Journal of Wood Anatomists, 39, 1-13.

Nakaba, S., Begum, S., Yamagishi, Y., Jin, H., Kubo, T., \& Funada, R. (2012a). Differences in the timing of cell death, differentiation and function among three different types of ray parenchyma cells in the hardwood Populus sieboldii $\times$ P. grandidentata. Trees, 26, 743-750.

Nakaba, S., Kubo, T., \& Funada, R. (2011). Nuclear DNA fragmentation during cell death of short-lived ray tracheids in the conifer Pinus densiflora. Journal of Plant Research, 124, 379-384.

Nakaba, S., Sano, Y., \& Funada, R. (2013). Disappearance of microtubules, nuclei and starch during cell death of ray parenchyma in Abies sachalinensis. IAWA Journal, 34, 135-146.

Nakaba, S., Sano, Y., Kubo, T., \& Funada, R. (2006). The positional distribution of cell death of ray parenchyma in a conifer, Abies sachalinensis. Plant Cell Reports, 25, 1143-1148.

Nakaba, S., Yamagishi, Y., Sano, Y., \& Funada, R. (2012b). Temporally and spatially controlled death of parenchyma cells is involved in heartwood formation in pith regions of branches of Robinia pseudoacacia var. inermis. Journal of Wood Science, 58, 69-76.

Nakaba, S., Yoshimoto, J., Kubo, T., \& Funada, R. (2008). Morphological changes in the cytoskeleton, nuclei, and vacuoles during cell death of short-lived ray tracheids in the conifer Pinus densiflora. Journal of Wood Science, 54, 509-514.

Nic-Can, G., Hernández-Castellano, S., Kú-González, A., Loyola-Vargas, V. M., \& Dela-Peña, C. (2013). An efficient immunodetection method for histone modifications in plants. Plant Methods, 9, 47.

Pfanz, H., Aschan, G., Langenfeld-Heyser, R., Wittmann, C., \& Loose, M. (2002). Ecology and ecophysiology of tree stems: Corticular and wood photosynthesis. Naturwissenschaften, 89, 147-162.

Plomion, C., Leprovost, G., \& Stokes, A. (2001). Wood formation in trees. Plant Physiology, 127, 1513-1523.

Potvin, C. (1979). A simple, modified methyl green-Pyronin Y stain for DNA and RNA in formalin-fixed tissues. Laboratory Medicine, 10, 772-774.

Pruyn, M. L., \& Spicer, R. (2012). Parenchyma. eLS, 1-8.

Rossi, S., Deslauriers, A., Anfodillo, T., \& Carraro, V. (2007). Evidence of threshold temperatures for xylogenesis in conifers at high altitudes. Oecologia, 152, 1-12.

Rossi, S., Deslauriers, A., Anfodillo, T., \& Carrer, M. (2008). Age-dependent xylogenesis in timberline conifers. New Phytologist, 177, 199-208.

Saranpaa, P. (1988). Plastids and glycolipids in the stemwood of Pinus sylvestris $L$. Trees, 2, 180-187.

Spicer, R. (2005). Senescence in secondary xylem: Heartwood formation as an active developmental program. In M. N. Holbrook \& M. A. Zwieniecki (Eds.), Vascular Transport in Plants (pp. 457-475). San Diego, SD: Elsevier Academic Press.

Spicer, R. (2014). Symplasmic networks in secondary vascular tissues: Parenchyma distribution and activity supporting long-distance transport. Journal of Experimental Botany, 65, 1829-1848.

Spicer, R., \& Holbrook, N. (2007). Parenchyma cell respiration and survival in secondary xylem: does metabolic activity decline with cell age? Plant, Cell and Environment, 30, 934-943.

Stewart, C., mos, G., \& Harvey, L. J. (1953). Chemical studies on Eucalyptus regnans F. Muell. Australian Journal of Biological Sciences, 6, 21-47.

Taylor, A. M., Gartner, B. L., \& Morrell, J. J. (2002). Heartwood formation and natural durability- a review. Wood Fiber Science, 34, 587-611.

van Cleve, B., Forreiter, C., Sauter, J. J., \& Apel, K. (1993). Pith cells of poplar contain photosynthetically active chloroplasts. Planta, 189, 70-73.

Van Lierde, J. (2013). What causes natural durability in Eucalyptus bosistoana timber? A dissertation submitted in partial fulfilment of the requirements for the degree of Bachelor of Forestry Science with Honours (B. For. Sci. (Hon)). Christchurch: University of Canterbury. 